Thorax (1967), 22, 473.

\title{
Communication between the left ventricle and right atrium
}

\author{
R. S. B A R C LAY, J . M. REID, E. N. COLEMAN, \\ J. G. STEVENSON, T. M. WELSH, AND N. M SWAN
}

From the Cardiothoracic Unit, Mearnskirk Hospital, and the University Department of Child Health, Royal Hospital for Sick Children, Glasgow

\begin{abstract}
A further 15 patients with left ventricular/right atrial communication are reported, 14 of whom were treated surgically. The clinical triad of a ventricular septal defect murmur, cardiac enlargement, and an arteriovenous shunt at atrial level is characteristic of the malformation. Of the 14 patients accorded surgical treatment, one died soon after operation. The remainder are well, with both the electrocardiographic signs of left ventricular hypertrophy and the radiographic evidence of cardiomegaly having undergone regression.
\end{abstract}

Until recently, communication between the left ventricle and the right atrium had been regarded as an extremely rare condition and of little clinical significance. The earliest report of this malformation was by Thurnam (1838) and Buhl (1857), and Hillier (1859) added further contributions. Thereafter there was a hiatus until Perry, Burchell, and Edwards (1949), reviewing five cases from the literature, added a sixth of their own. A further two cases reported by Stahlman, Kaplan, Helmsworth, Clark, and Scott (1955) were diagnosed, as were all the preceding cases, at necropsy, and it was not until Kirby, Johnson, and Zinsser (1957) successfully closed a left ventricular/right atrial shunt that the diagnosis was established during the life of a patient, albeit at the time of operation. With increasing awareness of this entity and with more refined and precise methods of cardiac investigation by means of cardiac catheterization and angiocardiography, further cases have been diagnosed pre-operatively and have been successfully operated on (Gerbode, Hultgren, Melrose, and Osborn, 1958; Braunwald and Morrow, 1960 ; Levy and Lillehei, 1962 ; and Mellins, Cheng, Ellis, Jameson, Malm, and Blumenthal, 1964).

We wish to record a further 15 patients who had a communication between the left ventricle and right atrium; they were collected over a period of six years, which would indicate that the anomaly is not so rare as was previously thought. All but one had surgical treatment, and our report is concerned with these. The fifteenth was an infant who had multiple congenital abnormalities, who developed congestive cardiac failure when 3 weeks old, and who was successfully digitalized but died of gastro-enteritis at 4 months. Cardiomegaly was accompanied by radiographic and electrocardiographic evidence of left ventricular hypertrophy and by evidence at cardiac catheterization of an arteriovenous shunt at atrial level: necropsy demonstrated a direct communication between the left ventricle and right atrium.

\section{MATERIAL}

During the period under review (1960 to 1966) 124 patients with ventricular septal defect have been operated on with the support of cardiopulmonary bypass at the Cardiothoracic Unit, Mearnskirk Hospital. This total includes $14(11 \%)$ with left ventricular/right atrial shunts and others with complicated malformations (Table I).

The relevant details of the 14 patients with communication between the left ventricle and the right atrium are presented in Table II. There were five males and nine females, the age range being from 2 to 23 years. The pre-operative diagnosis was not definitely established in any of our cases, inasmuch as selective angiocardiography performed in the left ventricle is the only incontrovertible means by which this may be achieved (Braunwald and Morrow, 1960 ; Taussig, 1960), and we are reluctant to perform this investigation in patients with ventricular septal defect, as the majority are young children. In our first three patients the diagnosis of this variant of ventricular septal defect was not even suspected prior to operation and was recognized only when the heart was 
T A B L E I

124 PATIENTS WITH VENTRICULAR SEPTAL DEFECT

\begin{tabular}{|c|c|c|c|c|c|c|}
\hline $\begin{array}{l}\text { V.S.D. as Sole } \\
\text { Anomaly }\end{array}$ & L.V.-R.A. Shunt & $\begin{array}{l}\text { V.S.D. }+ \\
\text { Pulm. Stenosis }\end{array}$ & V.S.D. + P.D.A. & V.S.D. + A.S.D. & $\begin{array}{l}\text { V.S.D. + A.S.D. + } \\
\text { Pulm. Stenosis }\end{array}$ & $\begin{array}{l}\text { V.S.D. }+ \\
\text { Aortic Stenosis }\end{array}$ \\
\hline 74 & 14 & 20 & 2 & 7 & 4 & 3 \\
\hline
\end{tabular}

T A B L E I I

PRE-OPERATIVE AND POST-OPERATIVE DATA ON 14 PATIENTS WITH COMMUNICATION BETWEEN LEFT VENTRICLE AND RIGHT ATRIUM

\begin{tabular}{|c|c|c|c|c|c|c|c|c|c|c|c|}
\hline No. & Age & Sex & $\begin{array}{l}\text { Pre-operative } \\
\text { E.C.G. }\end{array}$ & $\begin{array}{l}\text { Associated } \\
\text { Defects }\end{array}$ & $\begin{array}{c}\text { P.A. } \\
\text { Pressure } \\
\text { (mm. Hg) }\end{array}$ & $\begin{array}{c}\text { Type } \\
\text { of } \\
\text { Defect }\end{array}$ & $\begin{array}{c}\text { Date of } \\
\text { Opera- } \\
\text { tion }\end{array}$ & $\begin{array}{l}\text { Duration } \\
\text { of } \\
\text { Follow-up }\end{array}$ & $\begin{array}{l}\text { Residual } \\
\text { Murmur }\end{array}$ & $\begin{array}{c}\text { Post- } \\
\text { operative } \\
\text { E.C.G. }\end{array}$ & $\begin{array}{c}\text { Post- } \\
\text { operative } \\
\text { Radiograph }\end{array}$ \\
\hline 1 & 5 & F & L.V.H. & Nil & $40 / 18$ & Via tri- & 7.12 .60 & 6 years & Grade I systolic & Mild L.V.H. & Normal \\
\hline 2 & 17 & F & L.V.H. & A.S.D. & $20 / 10$ & $\begin{array}{l}\text { Via tri- } \\
\text { cuspid }\end{array}$ & 29. 3.61 & \multicolumn{4}{|c|}{$\begin{array}{l}\text { Died } 2 \text { days post-operatively from C.C.F. with aortic } \\
\text { regurgitation }\end{array}$} \\
\hline 3 & 3 & $\mathbf{M}$ & $\begin{array}{l}\text { L.V.H. + mild } \\
\text { R.V.H. }\end{array}$ & Nil & $35 / 10$ & $\begin{array}{l}\text { Via tri- } \\
\text { cuspid }\end{array}$ & 7. 1.62 & 4 years & Nil & Mild L.V.H. & $\begin{array}{l}\text { Still slight } \\
\text { L.V.H. }\end{array}$ \\
\hline 4 & 7 & $\mathbf{F}$ & $\begin{array}{l}\text { L.V.H.Complete } \\
\text { R.B.B.B.+1st }\end{array}$ & $\begin{array}{l}\text { Mild pulm. } \\
\text { stenosis }\end{array}$ & $\begin{array}{l}\text { R.V. 60/0 } \\
\text { P.A. 25/8 }\end{array}$ & $\begin{array}{l}\text { Via tri- } \\
\text { cuspid }\end{array}$ & 29. 8.62 & 4 years & Grade II systolic & $\begin{array}{l}\text { 1st degree } \\
\text { A.V.block }\end{array}$ & $\begin{array}{l}\text { Slight R.V. } \\
\text { enlargement }\end{array}$ \\
\hline 5 & 2 & $\mathbf{F}$ & $\begin{array}{l}\text { L.V.H. + partial } \\
\text { R.B.B.B. }\end{array}$ & A.S.D. & $28 / 8$ & Direct & 24. 4.63 & 3 years & Grade I systolic & $\begin{array}{l}\text { Partial } \\
\text { R.B.B.B. }\end{array}$ & $\begin{array}{l}\text { Still slight } \\
\text { L.V.H. }\end{array}$ \\
\hline 6 & 4 & $\mathbf{M}$ & $\begin{array}{l}\text { L.V.H. +partial } \\
\text { R.B.B.B. }\end{array}$ & A.S.D. & $24 / 9$ & Direct & 9.10 .63 & 3 years & Nil & Normal & Normal \\
\hline 7 & 4 & F & $\begin{array}{l}\text { Mild L.V.H. } \\
\text { partial R.B.B.B. }\end{array}$ & A.S.D. & $20 / 10$ & Direct & 1.11 .63 & 3 years & Grade I systolic & $\begin{array}{l}\text { Partial } \\
\text { R.B.B.B. }\end{array}$ & Slight L.V.H \\
\hline $\begin{array}{l}8 \\
9\end{array}$ & $\begin{array}{l}3 \\
4\end{array}$ & $\underset{M}{\mathrm{~F}}$ & $\begin{array}{l}\text { L.V.H. } \\
\text { Mild L.V.H. }+- \\
\text { partial R.B.B.B. }\end{array}$ & $\begin{array}{l}\text { Nil } \\
\text { A.S.D. }\end{array}$ & $\begin{array}{l}42 / 4 \\
20 / 8\end{array}$ & $\begin{array}{l}\text { Direct } \\
\text { Direct }\end{array}$ & $\begin{array}{ll}\text { 17. } & 1.64 \\
24 . & 1.64\end{array}$ & $\begin{array}{l}2 \text { years } \\
2 \text { years }\end{array}$ & $\begin{array}{l}\text { Nil } \\
\text { Grade I systolic }\end{array}$ & $\begin{array}{l}\text { Slight L.V.H. } \\
\text { Partial } \\
\text { R.B.B.B. }\end{array}$ & $\begin{array}{l}\text { Slight L.V.H } \\
\text { Slight L.V.H }\end{array}$ \\
\hline $\begin{array}{l}10 \\
11 \\
12 \\
13\end{array}$ & $\begin{array}{r}23 \\
5 \\
7 \\
6\end{array}$ & $\begin{array}{l}\mathbf{M} \\
\mathbf{F} \\
\mathbf{F} \\
\mathbf{F}\end{array}$ & $\begin{array}{l}\text { Mild L.V.H. } \\
\text { Partial R.B.B.B. } \\
\text { Normal } \\
\text { Mild L.V.H. }\end{array}$ & $\begin{array}{l}\text { Nil } \\
\text { A.S.D. } \\
\text { Nil } \\
\text { Nil }\end{array}$ & $\begin{array}{l}38 / 8 \\
20 / 8 \\
27 / 6 \\
20 / 8\end{array}$ & $\begin{array}{l}\text { Direct } \\
\text { Direct } \\
\text { Direct } \\
\text { Tricus- } \\
\text { pid }\end{array}$ & $\begin{array}{r}12.6 .64 \\
7.10 .64 \\
27.10 .65 \\
9.2 .66\end{array}$ & $\begin{array}{l}2 \text { years } \\
2 \text { years } \\
1 \text { year } \\
6 \text { months }\end{array}$ & $\begin{array}{l}\text { Grade I systolic } \\
\text { Nil } \\
\text { Nil } \\
\text { Nil }\end{array}$ & $\begin{array}{l}\text { Normal } \\
\text { Normal } \\
\text { Normal } \\
\text { Normal }\end{array}$ & $\begin{array}{l}\text { Norma! } \\
\text { Normal } \\
\text { Normal } \\
\text { Normal }\end{array}$ \\
\hline 14 & 3 & $\mathbf{M}$ & Mild L.V.H. & Nil & $24 / 8$ & Direct & 10.10 .66 & 2 months & Nil & - & - \\
\hline
\end{tabular}

L.V.H. = Left ventricular hypertrophy; R.V.H. $=$ right ventricular hypertrophy; R.B.B.B. $=$ right bundle-branch block; H.B. $=$ heart block; A.S.D. = atrial septal defect; A.V. = atrioventricular; C.C.F. = congestive cardiac failure.

opened. In the remaining 11 , the diagnosis was quite firmly predicted before operation from an association of clinical, radiological, and cardiac catheterization findings, of which we had by then become aware.

CLINICAL FINDINGS Exertional dyspnoea and undue lassitude were present in only two of our patients (cases 2 and 10). The remainder were symptomless. Case 10 had been admitted to another hospital eight months prior to operation with a pyrexial illness which subsequent investigation proved to be staphylococcal septicaemia and endocarditis. He made a complete recovery following the administration of cloxacillin. In all there was a grade IV pansystolic murmur along the left border of the sternum, maximal in intensity at the third or fourth interspace, and the second sound at the pulmonary area was accentuated but normally split. Right ventricular pulsation of varying degree was noted in most. The electrocardiogram did not prove particularly helpful; six showed partial right bundle-branch block with left ventricular hypertrophy, a further six showed left ventricular hypertrophy alone, and in one (case 4) there was firstdegree atrioventricular block.
On radiography cardiac enlargement was observed; $\underset{x}{\tilde{N}}$ in most the contour suggested enlargement of the left $:$ ventricle, right atrium, and pulmonary conus (Figs 3 . 1 and 2).

CARDIAC CATHETERIZATION Right heart catheterization was carried out in all, using either the saphenous or median basilic vein. The outstanding and uniform finding was the augmentation in oxygen saturation. occurring in the right atrium, although in six instances $N$ there was an additional but smaller increment in the N right ventricle. Pulmonary hypertension was detected ${ }^{\omega}$ in four, but in none was it more than mild. Selective angiocardiography carried out in the main pulmonarye artery can provide in the child an excellent picture $\Phi$ of the left heart chambers. Unfortunately, in many? of our earlier patients this examination was not 0 performed, and in another later in the series it had ${ }_{0}^{\circ}$ to be abandoned because of the onset of serious $\mathbb{D}$ arrhythmia. In three patients, however, the suspected $\frac{}{\mathbb{O}}$ diagnosis was virtually established by the angio- 0 cardiogram. 


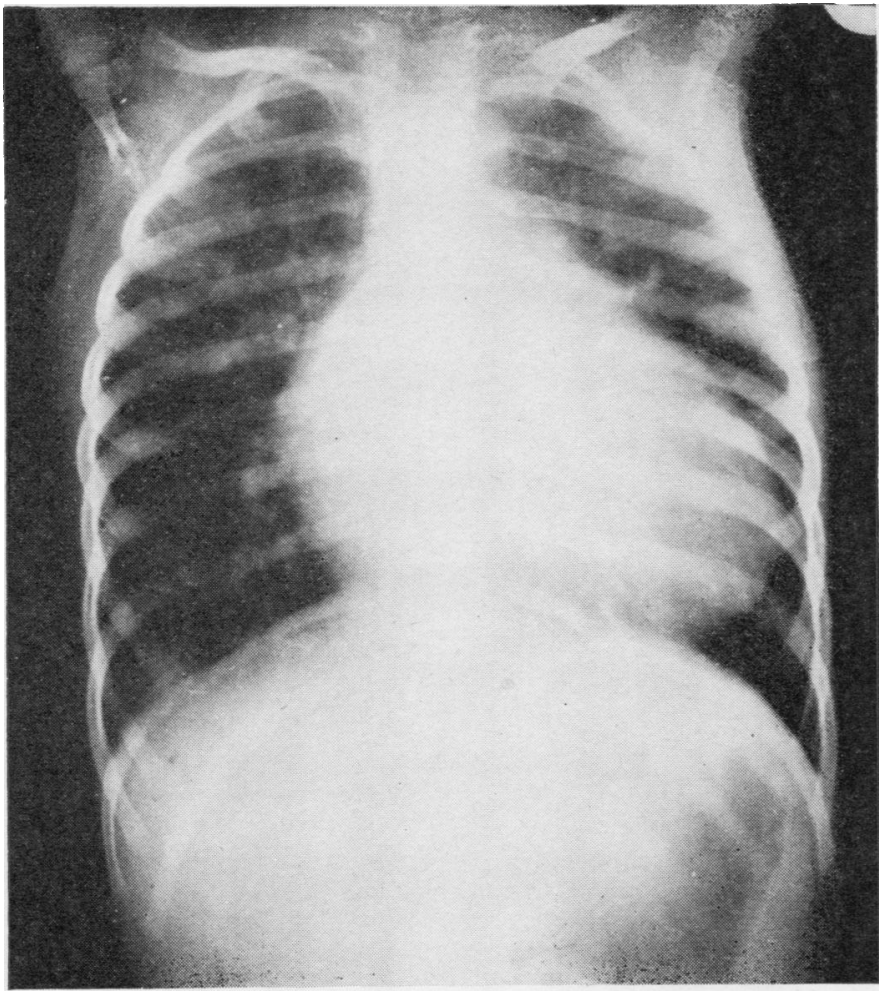

FIG. 1. Case 6. Pre-operative radiograph showing considerable enlargement of both the right atrium and the left ventricle.

OPERATIVE DATA The 14 patients were operated on using cardiopulmonary bypass with moderate hypothermia $\left(32^{\circ}\right.$ C.). The correot diagnosis was unsuspected in our first three patients, and the situation became apparent only after opening the ventricle and inspecting the septum. In the remaining 11 , because the diagnosis was strongly suspected, atriotomy was performed which enabled repair of the defect to be carried out and also closure in six instances of an atrial septal defect; ventriculotomy was not required in any of these cases although two were of the indirect type. Direot suture proved adequate, and in no case was a patch considered necessary. The patient who had accompanying pulmonary stenosis (Table II, case 4) underwent commissurotomy after closure of the defect.

Recovery was uneventful in 13 patients, but one (case 2) died two days after operation from cardiac failure with severe pulmonary congestion. It was suspected that aortic insufficiency had been produced during repair of the defect, the aortic cusps being distorted by the sutures; at necropsy this was confirmed.

POST-OPERATIVE STATUS The 13 survivors have been supervised by out-patient review since operation, the period ranging from three months to six years. All have remained well, although in six there remains an unimpressive systolic murmur (grade I) at the left sternal border. The pre-operative electrocardiographic evidence of left ventricular hypertrophy which was present in 12 has regressed in all but three; the firstdegree atrioventricular block of case 4 has not been affected by operation. Radiologically, there has been a diminution in cardiac size in nine patients; but four still have prominence of the left ventricle, although the pulmonary plethora has disappeared. We have not repeated cardiac catheterization because we are of the opinion that there is sufficient information from the clinical findings to indicate that the shunt has been either completely repaired or reduced to insignificant proportions.

\section{DISCUSSION}

Edwards (1953) demonstrated that there are two types of communication between the left ventricle and the right atrium (Fig. 3). In the first the defect in the membranous portion of the ventricular septum opens directly into the right atrium above the tricuspid valve (direct type). In the second, the defect, which lies lower in the membranous part of the septum, opens first into the right ventricle behind the septal leaflet of the tricuspid valve and 


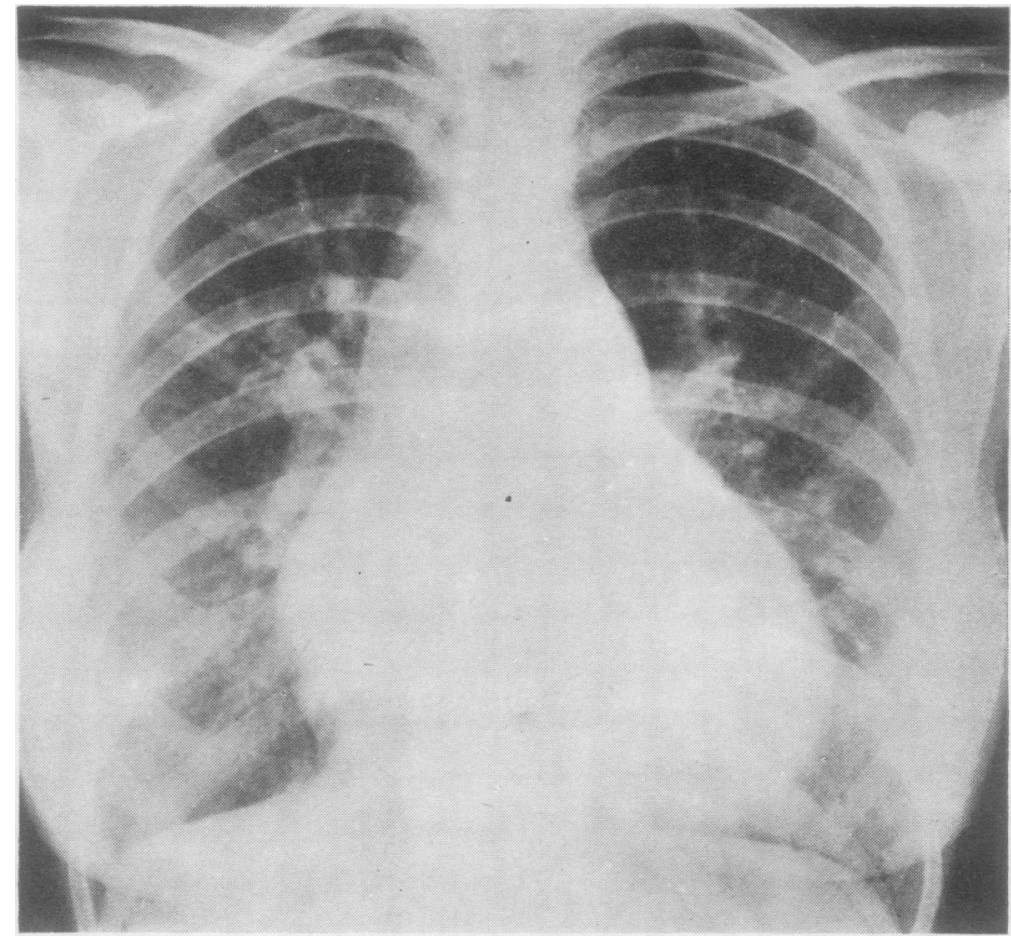

FIG. 2. Case 2. Pre-operative radiograph showing enlargement of both the right atrium and the left ventricle with prominence of the pulmonary conus.

thence into the right atrium through a second deficiency in the tricuspid valve which has, in turn, become closely adherent to the septum (indirect type). The shunt may thus be either solely from the left ventricle to the right atrium

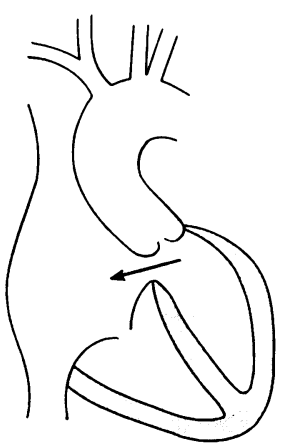

DIRECT

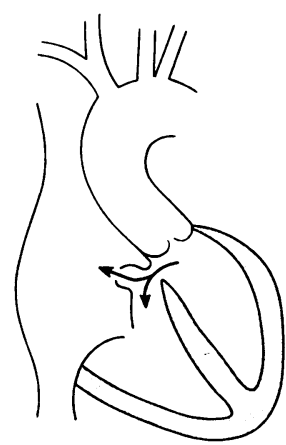

VIA TRICUSPID VALVE
FIG. 3. A diagrammatic representation showing the two types of communication between the left ventricle and the right atrium. or at both ventricular and atrial levels. Mellins et al. (1964) reviewed the 26 cases reported to that time and found that the indirect type was the more common (an incidence of 18 as opposed to eight of the direct type). Our experience has been to the contrary, inasmuch as in 10 out of our total of 15 patients the shunt was from the left ventricle directly to the right atrium. As the defect is situated in the atrioventricular portion of the membranous septum, not infrequently the mitral and tricuspid valves are abnormal and occasionally the outflow tract of either the right or left ventricle may be implicated. In none of our $N$ patients, however, was there abnormality of either the tricuspid or mitral valve necessitating repair, but one patient (case 4) had a mild obstruction of the outflow tract of the right ventricle. The one death which occurred was attributable to implication of an aortic valve cusp during surgical closure of a large defect ; this led to severe aortic regurgitation and cardiac failure very early post-operatively.

The classical triad, comprising the characteristic murmur of a ventricular septal defect, cardiac en- 
largement, and evidence at cardiac catheterization of a left-to-right shunt at atrial level, as enunciated by Taussig (1960), was present in all our cases. In addition to a substantial rise in oxygen saturation occurring at atrial level, we found a smaller but still significant rise in the right ventricle in six patients. This additional rise bore no relation either to the type of defect (direct or indirect) or to the presence of the concomitant atrial septal defect encountered in six patients.

Bacterial endocarditis is a relatively common complication of this malformation. In the case reported by Perry et al. (1949), infection was present at two separate sites, namely the tricuspid valve and the wall of the right ventricle. Mellins et al. (1964) recorded six patients with this defect, in two of whom there was unequivocal evidence of bacterial endocarditis, and in a further two circumstantial evidence. One of our patients had previously suffered from this complication but recovered rapidly following antibiotic therapy.

The electrocardiogram we have found to be of little assistance in distinguishing the condition from ventricular septal defect. Taussig (1960) stated that the findings were variable, depending on whether there were accompanying defects, but Levy and Lillehei (1962) considered that there was frequently a characteristic pattern. Tall and pointed $\mathbf{P}$ waves, indicative of right atrial enlargement, were observed in six of their 10 patients and a prolonged $\mathbf{P}-\mathbf{R}$ interval was also noted in six. Complete or incomplete right bundle-branch block was present in seven, and right or left or biventricular hypertrophy in varying degree was seen in most. We found partial right bundlebranch block in six of our patients, and left ventricular hypertrophy in twelve. Possibly this last feature is of importance, as it can in most instances make untenable the diagnosis of a secundum type atrial septal defect. Other possible diagnoses from which the lesion may have to be distinguished, particularly when anomalies of the tricuspid or mitral valves are present, are ostium primum atrial septal defect and persistent atrioventricular canal.

Undoubtedly for the majority of patients-those who have cardiomegaly and pulmonary plethora -surgical repair of the defect is indicated, and for this to be adequate cardiopulmonary bypass is necessary.

The authors wish to thank Mr. Hugh Gray, Department of Medical Illustration, Victoria Infirmary, Glasgow, for reproduction of the radiographs.

\section{REFERENCES}

Braunwald, E., and Morrow, G. (1960). Left ventricular-right atrial communication. Amer. J. Med., 28, 913.

Buhl, quoted by Meyer, H. (1857). Ueber angeborene Enge oder Verschluss der Lungenarterienbahn. Virchows Arch. path. Anat., $12,497$.

Edwards, J. E. (1953). Congenital malformations of the heart and great vessels. In S. E. Gould (ed.). Pathology of the Heart, p. 266. Thomas, Springfield, III.

Gerbode, F., Hultgren, H., Melrose, D., and Osborn, U. (1958) Syndrome of left ventricular-right atrial shunt. Ann. Surg., 148, 433.

Hillier, T. (1859). Congenital malformation of the heart; perforation of the septum ventriculorum, establishing a communication between the left ventricle and the right auricle. Trans. path. Soc Lond., 10, 110.

Kirby, C. K., Johnson, J., and Zinsser, H. F. (1957). Successful closure of a left ventricular-right atrial shunt. Ann. Surg., 145. 392.

Levy, M., and Lillehei, C. W. (1962). Left ventricular-right atrial canal. Ten cases treated surgically. Amer. J. Cardiol., 10, 623.

Mellins, R. B., Cheng, G., Ellis, K., Jameson, A. G., Malm, J. R., and Blumenthal, S. (1964). Ventricular septal defect with shunt from left ventricle to right atrium. Brit. Heart J., 26, 584.

Perry, E. L., Burchell, H. B., and Edwards, J. E. (1949). Congenital communication between the left ventricle and the right atrium: co-existing ventricular septal defect and double tricuspid orifice. co-existing ventricular septal
Proc. Mayo Clin., 24, 198.

Stahlman, M., Kaplan, S., Helmsworth, J. A., Clark, L. C., and Scott, H. W., Jr. (1955). Syndrome of left ventricular-right atrial shun resulting from high interventricular septal defect associated with defective septal leaflet of the tricuspid valve. Circulation, 12, 813 .

Taussig, H. B. (1960). Congenital Malformations of the Heart, 2nd ed., vol, 2 p. 718. The Commonwealth Fund, Harvard University Press, Cambridge, Mass.

Thurnam, J. (1838). On aneurysms of the heart. Trans. med. Soc. Lond., 21, 187. 